INTERNATIONAL JOURNAL OF RESEARCHES IN BIOSCIENCES, AGRICULTURE AND TECHNOLOGY (C) VISHWASHANTI MULTIPURPOSE SOCIETY (Global Peace Multipurpose Society) R. No. MH-659/13(N) www.vmsindia.org

\title{
ZOOPLANKTON DIVERSITY AND DENSITY IN SOME FRESHWATER BODIES AROUND SATARA (M.S) INDIA
}

\section{S. M. Pawar and V. B. Supugade}

Dept. of Zoology, Lal Bahadur Shastri College of Arts, Science and Commerce, Satara E-mail:sandhya pawar8@gmail.com

\section{Abstract-}

The present study deals with the diversity and density of zooplankton of three fresh water bodies from the Satara district. The present work is carried out from June 2012 to June 2013. There are five major groups of zooplanktons namely rotifers $>$ cope pods $>$ cladocearans $>$ protozoan $>$ ostracods. The study shows 66 s pecies of zooplanktons where rotifers dominates all other groups.

\section{Introduction-}

Freshwater zooplankton is an important component in an aquatic ecosyste $\mathrm{m}$ ad plays a critical role not only for primary consumers by serve as source of food for higher organisms. They are primary food for finished and sheel fishes and can be used as indicators of tropic status of water body. Their flucations in occurrence and abundance can be used to estimate the fishery potential of a water body. Hutchinson. G. E (1967)

Zooplankton plays a key role in transferring e nergy from one tropic level to other in the aquatic habitat. Besides, they are also used as biological indicators of tropic status of water body. Their patterns of distribution, periodicity, abundance and growth in different aquatic habitats have been subject to many researchers in India. Nasar. S. A. and Munshi J. S. D.C. (1975).

The Zooplankton community cons titutes an important component of aquatic eco-system and many species are suitable as line feed in aquaculture. The knowledge of their abundance, species diversity and special distribution is important in understanding trophodynamic and trophic progression of water bodies. Phytoplankton and Zooplankton undertake a journey from bottom to surface at the approach of darkness. Light intensity is considered the main factor, in addition to other factors like temperature, pressure, gravity and preadtors to influence this phenomenon. Sreelatha, K. and Rajalakas hmi. S. (2005).

They serve as a link between primary $\&$ tertiary production (forming major food source). Density of zooplankton is dire ctly corre lated with fishery potential. The present study deals with species diversity \& density of zooplankton of fresh water bodies at Kas, Kanher \& Mahadare rese rvoir.

\section{Material and Methods-}

The selected reservoirs are located Kas (N 174 $05^{\circ} 90 ; \mathrm{E} 73^{\circ} 4642^{\circ} 61$ ), Kanher
$\left(\mathrm{N} 17^{\circ} 44 \quad 16^{\circ} 02:\right.$ E $\left.73^{\circ} 5343^{\circ} 10\right)$ and Mahadare $\left(\mathrm{N} 17^{\circ} 4058^{\circ} 43:\right.$ E $\left.73^{\circ} 5822^{\circ} 92\right)$ reservoir from Satara district. From these reservoirs, water samples were collected for analys is of physic-chemical parameters, diversity and density of zooplanktons. The study was conducted for a period of June 2012 to June 2013.

Zooplankton samples were collected with plankton net at two times mesh size 45 micron \& $4 \%$ formaline was added to preserve the samples for further studies in the laboratory. The concentration of samples was examined under microscope. They were identified using standard literature such as APHA (1992), Fritsch (1965), Hutchinson (1957), Biswas (1980), and Edmondson (1963). The physico- chemical parameters were studied by using APHA (1992), Trivedy and Goel (1986). The concentration of samples for zooplanktons was collected after filtration of 50 liters of water to make volume 50 $\mathrm{ml}$ filtrate in plastic bottle and prese rved by using $0.5 \mathrm{ml}$ of formalin, examined unde r microscope \& were counted using Lackey's d rop method. Adoni etal, (1985).

The density of zooplankton was expressed as organisms per liter using formula $\mathrm{N}=\mathrm{n} * \mathrm{v} / \mathrm{V}$ Where, $\mathrm{N}=$ Total number of org. /lit. of water filtered.

$\mathrm{N}$ =number of organis $\mathrm{m}$ counted in $1 \mathrm{ml}$ of sample.

$\mathrm{v}=$ Volume of concentrated sample. $(\mathrm{ml})$

$\mathrm{V}=$ Volume of to tal water filtered / lit. (ml)

\section{Result and Discussion-}

Similar type of work has been reported by no. of workers. Hujare (2005) reported absences of any seasonal trend in ostracods on the basis of their work on Talsande \& Attigare reservoir. Pawar and Pulle (2005) recorded 60 species of zooplankton from Prthwadaj dam of Nanded. Pai and Berde (2005) reported $48 \& 50$ species of zooplankton from Sadoba pond of Kolhapur district and Santacruz Lake from Goa respectively. Kamble and Meshram (2005) 
recorded11 species of zooplankton from Khatijapur tank from Amaravati district. Pailwan et al., (2008) re corded 35 species of zoo planktons from 3 fre sh water Tanks of Kolhapur. Rajagopal et al., (2010) recorded 47 species of zooplanktons in Chinnapperkovil pond, $39 \mathrm{sp}$. in Nallanchettipatti pond \& 24 in Kadabamkulam pond of Tamilnadu. Shaikh et al., (2010) recorded 26 species of zooplanktons in fresh water bodies around Aurangabad. The rotifers are usually small microscopic pseudocoelomate animals which have been variously re garded as a separate phylum. It was dominating group as species of rotifers were recorded highest in the summer $(\mathrm{mg} / \mathrm{l})$ at Mahadare and lowe st at in rainy season at Kas reservoir. The density of Zooplankton is highest at Mahadare reservoir as compared with two other water bodies.

Table. 1. Dive rsity of zooplank to $n$ in three rese rvoirs

\begin{tabular}{|c|c|c|c|}
\hline Sr.no & Plankton recorded & Sr.no & Plankton recorded \\
\hline 1 & Brachionus angularis & 34 & Mesocyclops.sp, \\
\hline 2 & Brachionus bidentata & 35 & Mesocyclops leukartii \\
\hline 3 & Brachionus caudatus & 36 & Microcyclops sp., \\
\hline 4 & Brachionus calafertus & 37 & Nauplius larva \\
\hline 5 & Brachionus clayciforus & 38 & Phyllodiaptomus blanci \\
\hline 6 & Brachionus diversicornis & 39 & Alona sp., \\
\hline 7 & Brachionus durgae & 40 & Alona pulchella \\
\hline 8 & Brachionus falcatus & 41 & Bosminia sp., \\
\hline 9 & Brachionus forficula & 42 & Bosminia deiteri \\
\hline 10 & Brachionus pallas & 43 & Bosminia longirostris \\
\hline 11 & Brachionus quadridentata & 44 & Ceriodaphnia cornuta \\
\hline 12 & Brachionus rubens & 45 & Ceriodaphnia laticaudata \\
\hline 13 & Euchlanis dilatata & 46 & Daphnia longirimis \\
\hline 14 & Filinia bory & 47 & Daphnia lumholtzi \\
\hline 15 & Filinia terminales & 48 & Daphnia pulex \\
\hline 16 & Filinia longistea & 49 & Daphnia vosea \\
\hline 17 & Keratella bory & 50 & Diaphnasama excisum \\
\hline 18 & Keratella cochleraris & 51 & Indialona ganapati \\
\hline 19 & Keratella procurca & 52 & Monia sp., \\
\hline 20 & Keratella quadrata & 53 & Monia brachiata jurine \\
\hline 21 & Keratella tropica & 54 & Monia macrocopa \\
\hline 22 & Lecane sp., & 55 & Monia mircrura \\
\hline 23 & Lecane closterocerca & 56 & Sida crystallina \\
\hline 24 & Lecane hamata & 57 & Cypris sp., \\
\hline 25 & Lecane luna & 58 & Cyclocypris globosa \\
\hline 26 & Lecane stichaea & 59 & Ste nocypris sp., \\
\hline 27 & Natholca acuminate & 60 & Amoeba sp., \\
\hline 28 & Polyarthra vulgaris & 61 & Amoeba radiosa \\
\hline 29 & Trichocera porcellus & 62 & Arcella sp., \\
\hline 30 & Argulus foliceous & 63 & Diffugia sp. \\
\hline 31 & Cyclops sp., & 64 & Paramecium sp., \\
\hline 32 & Diopto mus sp., & 65 & Trinema sp., \\
\hline 33 & Heleodiaptomus vidaus & 66 & Vorticella sp., \\
\hline
\end{tabular}

Table: 2. \% population of Zooplankton diversity in Kas reservoir

\begin{tabular}{|l|l|l|l|l|}
\hline Season & Rotifers & Cladocerans & Copepods & Ostracods \\
\hline Rainy & $42.01 \%$ & $24.21 \%$ & $13.87 \%$ & $2.45 \%$ \\
Winter & $42.48 \%$ & $37.64 \%$ & $21.69 \%$ & $1.50 \%$ \\
\hline Summer & $59.70 \%$ & $28.34 \%$ & $30.99 \%$ & $2.11 \%$ \\
\hline
\end{tabular}

Table: 3. \% population of Zooplankton diversity in Kanher reservoir

\begin{tabular}{|l|l|l|l|l|}
\hline Season & Rotifers & Cladocerans & Copepods & Ostracods \\
\hline Rainy & $50.55 \%$ & $20.54 \%$ & $24.49 \%$ & $4.11 \%$ \\
\hline Winter & $40.50 \%$ & $36.54 \%$ & $22.27 \%$ & $1.50 \%$ \\
\hline Summer & $55.56 \%$ & $13.85 \%$ & $28.51 \%$ & $2.11 \%$ \\
\hline
\end{tabular}

Table: 4. \% population of Zooplankton diversity in Mahadare rese rvoir

\begin{tabular}{|l|l|l|l|l|}
\hline Season & Rotifers & Cladocerans & Copepods & Ostracods \\
\hline Rain & $56.01 \%$ & $16.22 \%$ & $17.17 \%$ & $4.00 \%$ \\
\hline Winter & $43.83 \%$ & $23.67 \%$ & $21.40 \%$ & $1.32 \%$ \\
\hline Summer & $64.16 \%$ & $18.55 \%$ & $31.03 \%$ & $4.10 \%$ \\
\hline
\end{tabular}


Figure. 1. Zooplank to n diversity of Kas rese rvoir during June 2012- June 2013

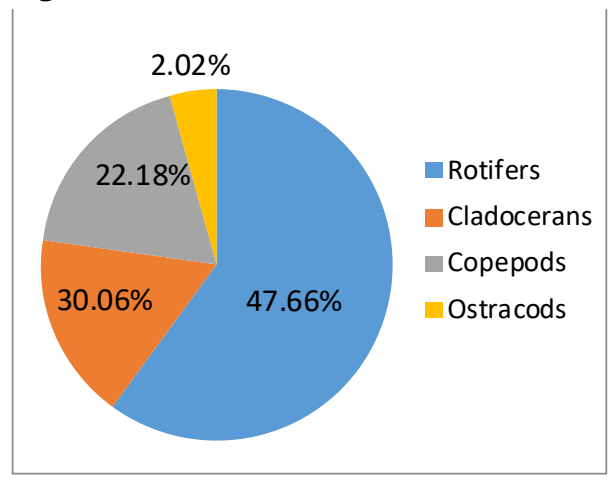

Figure 2. Zooplankton diversity of Kanher dam during Ju ne 2012- June 2013

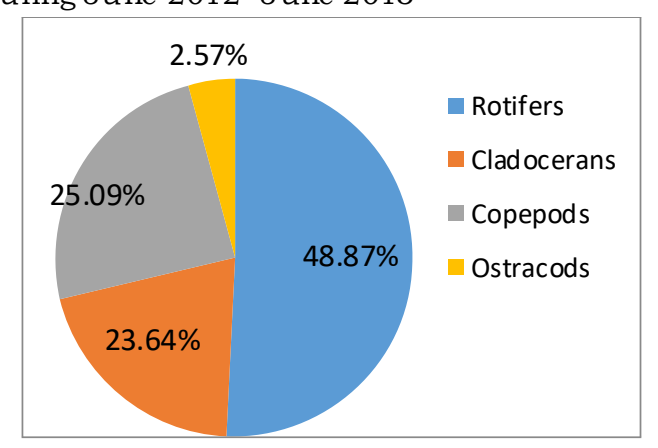

Figure 3. Zooplankton diversity of Mahadare rese rvoir during June 2012- June 2013

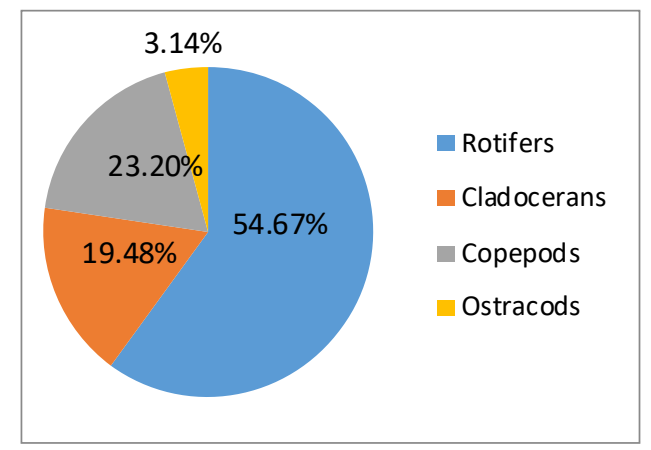

\section{Acknowledgement-}

Author is thankful to Principal Dr. R. V. Shejawal for providing all ne cessary facilities and encou rageme nt during research work.

\section{References-}

1. Adoni. A.D., Joshi G. Chourasia S.K., Vaishya A.K., Yadav. M. \& Ve rma H.G. (1985) A workbook on Limnology.Publis hed by department of botany .Dr. harising Gaur Vishwavidyalaya Sagar, India.
2. APHA 1992. Standard methods for examination of water and waste waters. American Public Health Association, 18 th Edition. Washington: DC.

3. Biswas K 1980. Common fresh and brackish water algal flora of India and Burma Botanical Survey of India. Govt. of India. XV: 105 pp. 10.

4. Chandrashekhar S.V.S. (1997) . Ecological Studies Saroornagar lake, Hyd rabad

5. Ugale B.J., Hiware C.J.., Jadhav B.V. \& Pathan D.M. (2005). Zooplankton dive rsity in Jagatunga Samudra re servoir, Kandhar, Nanded District . J.Aqua. Biol. 20 (2)49-52.

6. Edmondson, W.T. (1963) Fresh water biology. 2 nd Edition, John Wiley \& Sons, Inc. p. 1248.

7. Nasar. S. A. and Munshi J. S. D.C. (1975): Studies of primary protection of freshwater pond Jap. J E col. 25:21 23.

8. Sreelatha, K. and Rajalakashmi. S. (2005). Phytoplankton diversity of Goutami Godavari estuary at Yanam U.T. Pondicherry. J. Aqua. Biol. 20 (2.) 45.

9. Hutchinson. G. E (1967): A treative on limnology- II introduction to lake biology and the limnoplankton John Wily and Sons. Inc. New York- 1115.

10. Hujare M S 2005 Hydrobiological studies on some water reservoirs of Hatkanangale Tahsil (M.S.) Ph.D Thesis. Shivaji University, Kolhapur.

11. Kamble B B and Meshram C B 2005. A preliminary study on zooplankton diversity of Khatijapur tank, Dist. Amravati, (M.S.) India. J. Aqua. Biol. Vol. 20 (2): pp. 45-47.

12. Pai I K and Berde V 2005. Comparative studies on Limnology of freshwater bodies located in costal and high altitude of Goa and Maharashtra .India. J. Aqua. Biol. Vol. 20 (2): pp. 95-100.

13. Pailwan I F Muley D V Suryakant Maske 2008: Limnological features, plankton diversity, fishery status of three fresh water perennial tanks of Kolhapur district (M.S.) Proceeding. The World Lake Confe re nce pp.1643-1649.,

14.Pawar S K and Pulle J S 2005. Qualitative and Quantitative study of zooplankton in Pethwadaj dam Nanded district (M.S.) India. J. Aqua. Biol. Vol. 20 (2): pp. 53-57.

15.Shaikh R S, Mokashe S S and Kulkarni G K 2010. Zooplankton dive rsity in fresh water bodies around Aurangabad, (M.S.) India. J. Flora and Fauna .16 (2); pp. 249-256.

16.Trivedy R K and Goel P K 1986. Chemical and Biological methods for Water Pollution Studies, Env. Publications, Karad, pp. 247. 